\title{
Evaluate Kasmazan Impoundment Water for Irrigation Purposes
}

\author{
Akram O. Esmail*,Pakhshan M. Maulood ${ }^{\circ}$ \\ \&Yahya A. Shekha
}

*Soil and water Department, College of Agriculture, University of Salahaddin-Erbil.

- Biology Department, College of Science, University of Salahaddin - Erbil.$$
\text { اللخالاصة }
$$$$
\text { تم جمع عينات ماء في خمس مواقع من مسطح كسنز ان لمدة سبعة أشهر أبتذاء مهن }
$$

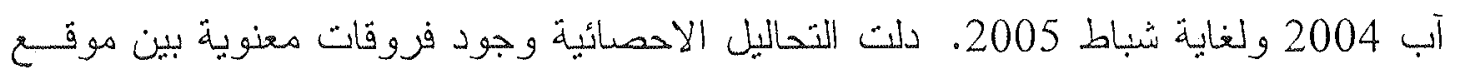

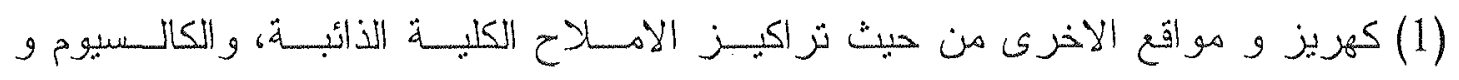

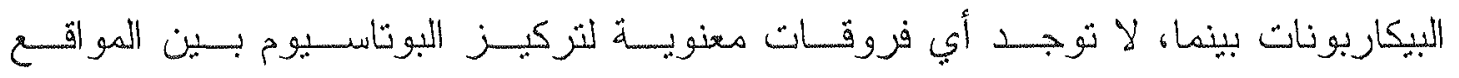

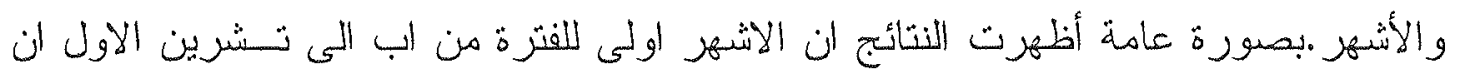

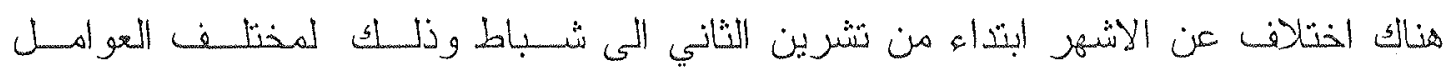$$
\text { الكبميائية. }
$$

\section{Abstract}

Water samples were collected monthly during August 2004 to February 2005 in five locations of Kasnazan impoundment $(10 \mathrm{Km}$ east side of Erbil city). Statistical analysis indicated that there were a significant differences between Kahreez site 1 and other sites in TDS, $\mathrm{Ca}^{+2}$, and $\mathrm{HCO}^{3-}$ values. While, there were no significant differences in $\mathrm{K}^{+}$concentration between stations or months.

Generally, the first three months (August to November) differed from the last four month (December to February) in most chemical properties.

\section{Introduction:-}

Water is essential for maintaining adequate food supply and a productive environment for human, animal and plant population. World agriculture consumes approximately $70 \%$ of freshwater withdrawn per Education, 4-5 September 2007 
[ Evaluate Kasnazan Impoundment...

year (1and 2). The amount of irrigated land in Kurdistan is expending very slowly because of water shortage for irrigation.

The water quality of the impoundment for irrigation is depends on the water resources, surrounding chemical composition of recatch area,

impoundment run-off water, environmental factors, etc. (3). Many limnological studies were conducted on kasnazan impoundment water $(4,5,6,7$ and 8$)$. While, this study is an attempt to study ionic composition and quality of impoundment water and its suitability for irrigation. Whereas, other studies it with water quality and classification depending on ionic compositions and ion pairs as (Esmail ${ }^{(9)}$, Esmail ${ }^{(10)}$ and Dohuki (11) ) in Erbil and Dohuk area of ground water for different purposes.

The most important classifications for irrigation water are:

1- United State Salinity Laboratory Staff ${ }^{(12)}$ classified irrigation water to sixteen classes depending on $\mathrm{dS} . \mathrm{m}^{-1}$ at $25^{\circ} \mathrm{C}$ and $\mathrm{SAR}$ as follows:

\begin{tabular}{|c|c|}
\hline Water Classes & $\begin{array}{c}\text { Electrical Conductivity } \mathrm{dS}_{\mathbf{m}} \mathbf{m}^{-1} \text { at } \\
\mathbf{2 5}{ }^{\circ} \mathrm{C}\end{array}$ \\
\hline C1 Low- salinity & $0<\mathrm{EC}<0.25$ \\
\hline C2 Medium- salinity & $0.25<\mathrm{EC}<0.75$ \\
\hline C3 High - salinity & $0.75<\mathrm{EC}<2.25$ \\
\hline C4 Very high -salinity & $2.25<\mathrm{EC}<5$ \\
\hline
\end{tabular}

\begin{tabular}{|c|c|}
\hline Water Classes & SAR \\
\hline S1= Excellent & $<10$ \\
\hline S2= Good & $10-18$ \\
\hline S3 = Fair & $18-26$ \\
\hline S4= Poor & $>26$ \\
\hline
\end{tabular}

2- Todd ${ }^{(13)}$ classification of irrigation water based on total dissolved salts (TDS), chloride content and sodium percentage as follows:

\begin{tabular}{|c|c|c|c|}
\hline \multirow{2}{*}{ Elements } & \multicolumn{3}{|c|}{ Water classes } \\
\cline { 2 - 4 } & Suitable & Moderate & Doubtful \\
\hline $\mathrm{TDS}(\mathrm{ppm})$ & 700 & 2000 & $>2000$ \\
\hline $\mathrm{Cl}(\mathrm{ppm})$ & 150 & 500 & $>500$ \\
\hline $\mathrm{Na} \%$ & 60 & $60-75$ & $>75$ \\
\hline
\end{tabular}


3-Don ${ }^{(14)}$ classified irrigation water depending up on total salt content, $\mathrm{EC}, \mathrm{SAR}, \mathrm{Na} \%$ and $\mathrm{pH}$ to four classes as follow:

\begin{tabular}{|c|c|c|c|c|c|}
\hline $\begin{array}{c}\text { Water } \\
\text { quality }\end{array}$ & $\begin{array}{c}\mathrm{EC} \\
\mathbf{d S . \mathbf { S } ^ { - 1 }}\end{array}$ & $\begin{array}{c}\text { Total } \\
\text { soluble } \\
\text { salt(ppm) }\end{array}$ & $\begin{array}{c}\text { Sodium } \\
\text { content } \\
(\% \text { salt as } \\
\mathrm{Na})\end{array}$ & SAR & $\mathrm{pH}$ \\
\hline Excellent & 0.25 & 175 & 20 & 3 & 6.5 \\
\hline Good & $0.25-0.75$ & $175-525$ & $20-40$ & $3-5$ & $6.5-6.8$ \\
\hline Permissible & $0.75-2.0$ & $525-1400$ & $40-60$ & $5-10$ & $6.8-7.0$ \\
\hline Doubtful & $2.0-3.0$ & $1400-2100$ & $60-80$ & $10-15$ & $7.0-8.0$ \\
\hline Unsuitable & $>3.0$ & $>2100$ & $>80$ & $>15$ & $>8.0$ \\
\hline
\end{tabular}

\section{Materials and Methods:}

Kasnazan impoundment is a large artificial water body designed to collect water from the perennial kahreez (in Kasnazan 10km east of Erbil city, with an altitude of $646 \mathrm{~m}$, latitude $38^{\circ} \mathrm{S} 0423768$, and longitude $40^{\circ}$ 07776MTM(8).

Water samples were collected monthly during August 2004 to February 2005. TDS,EC and pH were measured using ( pH-EC TDS meter, HI 9812, Hanna Instrument), while sodium, potassium, calcium, magnesium, bicarbonate and chloride contents were estimated according to Rayan et $\mathrm{al}^{(15)}$. Data were analyzed by SPSS (version 11) using Student-Newman-Keuls(SNK) after ANOVA, data were expressed as mean \pm S.E, $\mathrm{P}<0.05$ was considered as statistical significant.

\section{Result and Discussion:}

\section{A-Effect of time of sampling on some chemical compositions:}

Table(1), shows $\mathrm{pH}$ value and concentration of some ions for kasnazan impoundment water, the $\mathrm{pH}$ values ranged from 7.1 to 8.06, the lowest $\mathrm{pH}$ value was recorded during August 2004 which differ significantly from its value during other months, this may be due to variation in chemical composition of water from month to other or may be due to high concentration of $\mathrm{HCO}_{3}$ and low concentration of $\mathrm{Na}^{+}$(table 3 and 4).

The $\mathrm{Mg}^{+2} / \mathrm{Ca}^{+2}$ ratio exceed 1 , therefore, the water was classified as harmful for irrigation(16), this may be due to the dominancy of $\mathrm{Mg}^{+2}$ ion in comparison to $\mathrm{Ca}^{+2}$ (table 2), which may be return to presenting dolomite in catchments area (17).

The ratio between $\mathrm{Na}^{+} / \mathrm{Ca}^{+2}$ on October 2004 differed significantly from other months and its value was very high in compared with other months, and SSP was also high, but the water was suitable for 
irrigation because the initial concentration of single cations was low. On the other hand, the dominate cations was $\mathrm{Na}^{+}$while the dominate anion is was $\mathrm{Cl}-$, which ment that the family of water is $\mathrm{Na}-\mathrm{Cl}$, these results requires further studies in this area since most other studies in our country refers to the dominance of $\mathrm{Ca}^{+2}$ and $\mathrm{HCO}_{3}$ in water $(9,10$, and 11$)$.

The maximum concentration of chloride was 0.585 Meq. $\mathrm{l}^{-1}$ (fig.1), according to Van Hoorn ${ }^{(18)}$ the water is suitable for irrigation of all types of plants. While, no significant differences not observed between stations, (table3).

The concentration of $\mathrm{HCO}^{3-}$ in February was differed significantly from its concentration during other months, this may be due to the increase in dissolving $\mathrm{CO}_{2}$ in water with in this month which caused recording the highest concentration (0.045 Meq.l-1) for HCO3 (fig.2).

Fig.(3) shows the significant effect of period on EC value, the highest value $(0.66 \mathrm{dS} . \mathrm{m}-1)$ was recorded in February, while lowest value $(0.29 \mathrm{dS} . \mathrm{m}-1)$ was recorded in August, this variation may be due to variation in environmental factor, discharge of water,...etc. Depending on EC value this water classified as $\left(\mathrm{C}_{2}\right)$ or medium salinity according to Richards ${ }^{(19)}$ On the other hand, depending on SAR value water classified as (S1), (fig.4), which means that depending on United State Salinity Laboratory ${ }^{(12)}$ Kasnazan water can be classified as (C2S1) class. The class of the studied water was not affected by the time of sampling because the highest value of $\mathrm{Na}^{+}$ $\left(0.42\right.$ meq. $\left.\mathrm{l}^{-1}\right)$ was recorded during September, which is regarded as a very low concentration, fig.(5).

\section{B- Effect of stations on chemical composition of water:-}

The $\mathrm{pH}$ values of stations ranged between (7.5-7.9), the statistical analysis showed non significant difference between the $\mathrm{pH}$ value of the studied stations, fig.(6). According to (Richards ${ }^{(19)}$, Todd ${ }^{(20)}$, Ayers $^{(21)}$ and Iraqi Ecological Improvement and Protection Office ${ }^{(22)}$ ). water of these stations regards as water without problem for irrigation, while depending on Iraqi Ecological Improvement and Protection Office ${ }^{(20)}$ the studied water are located within upper desirable limit.

On the other hand, the statistical analysis indicated significant effect of stations or site of sampling on TDS, $\mathrm{Ca}^{+2}$ and $\mathrm{HCO}^{3-}$ concentrations, fig.( 7 and 8 ), while the other studied parameters were not affected by station of sampling, this explain the role of site or station of sampling within the same impoundment water in the effect on chemical composition and quality of water. It is appear that concentration of $\mathrm{Ca}^{+2}$ and $\mathrm{HCO}^{3-}$ among ions were different between stations with $\mathrm{Kahreez}$, this 
- $\left.4 \begin{array}{c}\text { Akram O. Esmail, Pakhshan M. Maulood } \\ \text { \&Yahva A. Shekha }\end{array}\right]$

may be due to the effect or rainfall on dissolving of (CaCO3) in catchments area because the rainfall have negative saturation index (9), and if the water have -ve saturation index, this means that water causes the dissolving of $\mathrm{CaCO} 3$ in the catchment's area which increase in their concentration in the water.

Table ( 3 and 4 ) shows that stations did not effected significantly $\mathrm{Mg}^{+2} / \mathrm{Ca}^{+2}, \mathrm{Na}^{+} / \mathrm{Ca}^{+2}$ SAR,SSP and SSPP, this may be due to continuous mixing of water from Kahreez with water of different stations.

\section{References}

1- UNESCO. United Nations Educational,Scientific and Cultural Organization. Securing the food supply. Paris:UNESCO.(2001).

2-- Pimentel,D. ; Berger,B. ; Filiberto,O. ; Newton,M. ; Wolfe,B. ; Karabinakis,E. ; Clark,S. ; Poon,E. ; Abbett,E. and Nandgopal,S. BioScience Journal.54(10):909-918. (2004).

3- Nakasone,H. and Kuroda, H. Journal. Vol.4:135-141.(1999).

4- Rasheed,R.O. A limnological. M.Sc. Thesis. University of Salahaddin-Erbil,Iraq.(1994).

5- Al-Barazingy,Y.O. M.Sc. Thesis. University of SalahaddinErbil,Iraq. (1995).

6- Toma,J.J. Journal of Babylon University ,Iraq. 10(3). (2004).

7- Bapeer, U.H.K. Ph.D. Thesis. University of SalahaddinErbil,Iraq.(2004).

8- Goran,S.M.A. M.Sc.Thesis. University of SalahaddinErbil,Iraq.(2006).

9- Esmail,A.O. Ph.D. Thesis. University of Baghdad.Iraq.(1992). ( In Arabic).

10-Esmail,A.U. M.Sc. Thesis. University of Salahaddin-Erbil,Iraq. (1986). (In Arabic).

11-Dohuki,M.S.S. M.Sc. Thesis. University of Salahaddin-Erbil, Iraq.(1997).( In Arabic).

12-United State Salinity Laboratory Staff. Diagnosis and improvement of saline and alkali soils.(1954). Ed. By Richards (1954).

13-Todd,D.K. University College Station,Texas.(1995).

14- Don,C.M. University College Station, Texas.(1995).

15-Ryan,J. ; Estefon,G. and Rashid, A. Soil and plant analysis laboratory manual. $2^{\text {nd }}$ Edition. National Agriculture ResearchCenter. Islamabad,Pakistan(2001).

16-Paliwal,K.V. NewDelhi. India.(1972).

17-Ause,R.Y.I. M.Sc. Thesis. Mosul University.Iraq.(1990). ( In Arabic). 


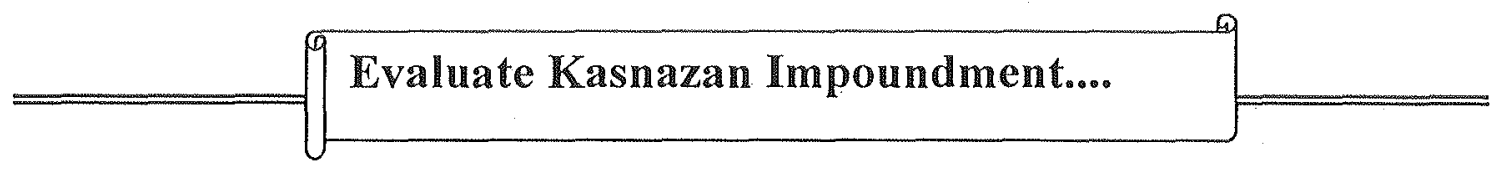

18-Van Hoorn,J.W. Irrigation and drainage paper 7. Salinity Seminar. Baghdad.FAO.Rome.(1970).

19-Richards,L.A. Diagnosis and improvement of saline and alkali soils. Agriculture hand book. No.60,USDA, Washington.(1954).

20-Todd,D.K. The water encyclopedia. Water Information Center.USA.(1970).

21-Ayers,R.S. and Westcot,D.W. Water quality for agriculture. Irrigation and Drianage Paper,29 Rev.1) FAO,Rome, Italy.(1985).

22-Iraqi Ecological Improvement and Protection Office. Iraqi Legislation. Ministry of Health. Baghdad.(1988). 
Table(1): shows some chemical properties of Kasnazan impoundment water during the studied period.Values expressed as a (mean \pm Standard Error).

\begin{tabular}{|c|c|c|c|c|c|c|}
\hline \multicolumn{2}{|c|}{ Months } & $\mathrm{pH}$ & TDS & Total hardness & $\mathrm{Na} / \mathrm{Ca}$ & $\mathrm{Mg} / \mathrm{Ca}$ \\
\hline \multirow{5}{*}{ 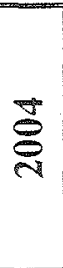 } & Aug. & $7.10 \pm 0.130^{2}$ & $214.0 \pm 12.08^{2 b}$ & $198.8 \pm 7.490^{\mathrm{abc}}$ & $3.58 \pm 0.392^{\mathrm{a}}$ & $1.17 \pm 0.172^{2}$ \\
\hline & Sep. & $7.88 \pm 0.146^{b}$ & $198.0 \pm 25.57^{\mathrm{ab}}$ & $169.8 \pm 18.10^{\mathrm{ab}}$ & $4.94 \pm 0.671^{2}$ & $1.44 \pm 0.121^{2}$ \\
\hline & Oct. & $7.96 \pm 0.169^{6}$ & $154.0 \pm 24.00^{\mathrm{a}}$ & $145.2 \pm 23.12^{\mathrm{a}}$ & $8.03 \pm 1.498^{b}$ & $2.37 \pm 0.400^{6}$ \\
\hline & Nov. & $8.06 \pm 0.092^{b}$ & $176.0 \pm 23.57^{\mathrm{ab}}$ & $167.0 \pm 18.51^{\mathrm{ab}}$ & $3.78 \pm 0.631^{2}$ & $2.50 \pm 0.169^{b}$ \\
\hline & Dec. & $7.61 \pm 0.050^{6}$ & $222.0 \pm 17.14^{\mathrm{ab}}$ & $218.8 \pm 12.73^{b c}$ & $4.22 \pm 0.475^{\mathrm{a}}$ & $3.22 \pm 0.391^{b}$ \\
\hline \multirow{2}{*}{$\stackrel{n}{\stackrel{\sim}{(}}$} & Jan. & $8.06 \pm 0.040^{6}$ & $242.0 \pm 12.00^{b}$ & $235.0 \pm 4.070^{c}$ & $1.84 \pm 0.447^{\mathrm{a}}$ & $1.45 \pm 0.171^{2}$ \\
\hline & Feb. & $7.84 \pm 0.107^{b}$ & $248.0 \pm 3.740^{b}$ & $254.0 \pm 5.610^{\mathrm{c}}$ & $1.98 \pm 0.074^{\mathrm{a}}$ & $1.37 \pm 0.098^{2}$ \\
\hline
\end{tabular}

Note: Values in each rows with different letters are significantly different at $\mathrm{P}<0.05$ according to $\mathrm{SNK}$ test. Values in rows with same Letters are no: significantly different.

Table(2): shows some chemical properties of Kasnazan impoundment water during the studied period.Values expressed as a (mean \pm Standard Error).

\begin{tabular}{|c|c|c|c|c|c|c|}
\hline \multicolumn{2}{|c|}{ Months } & $\begin{array}{c}\mathrm{Ca}^{+2} \\
\left(\mathrm{Meq} \cdot \mathrm{I}^{-1}\right)\end{array}$ & $\begin{array}{c}\mathrm{Mg}^{+2} \\
\left(\mathrm{Meq} \cdot \mathrm{I}^{-1}\right)\end{array}$ & $\begin{array}{c}\mathrm{K}^{+} \\
\text {(Meq. } \mathrm{I}^{-1} \text { ) }\end{array}$ & SSP & SSPP \\
\hline \multirow{5}{*}{ ষ্े } & Aug. & $0.119 \pm 0.108^{b c}$ & $0.132 \pm 0.007^{\mathrm{a}}$ & $0.058 \pm 0.006^{2}$ & $56.78 \pm 1.145^{\mathrm{a}}$ & $1.039 \pm 0.047^{\mathrm{a}}$ \\
\hline & Sep. & $0.093 \pm 0.146^{a b c}$ & $0.127 \pm 0.005^{\mathrm{a}}$ & $0.099 \pm 0.047^{\mathrm{a}}$ & $57.42 \pm 3.338^{\mathrm{a}}$ & $1.118 \pm 0.054^{\mathrm{a}}$ \\
\hline & Oct. & $0.068 \pm 0.224^{\mathrm{a}}$ & $0.127 \pm 0.001^{\mathrm{a}}$ & $0.053 \pm 0.002^{2}$ & $62.74 \pm 2.862^{\mathrm{a}}$ & $1.235 \pm 0.076^{a}$ \\
\hline & Nov. & $0.066 \pm 0.004^{a}$ & $0.167 \pm 0.023^{a b}$ & $0.096 \pm 0.012^{2}$ & $41.94 \pm 3.988^{b}$ & $0.615 \pm 0.087^{b}$ \\
\hline & Dec. & $0.077 \pm 0.011^{\mathrm{ab}}$ & $0.235 \pm 0.009^{c}$ & $0.054 \pm 0.002^{2}$ & $45.18 \pm 1.201^{b}$ & $0.694 \pm 0.023^{b}$ \\
\hline \multirow{2}{*}{ 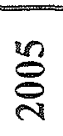 } & Jan. & $0.127 \pm 0.009^{c}$ & $0.179 \pm 0.011^{b}$ & $0.050 \pm 0.006^{\mathrm{a}}$ & $39.52 \pm 4.361^{b}$ & $0.555 \pm 0.090^{b}$ \\
\hline & Feb. & $0.139 \pm 0.006^{c}$ & $0.190 \pm 0.007^{b}$ & $0.061 \pm 0.005^{a}$ & $41.30 \pm 0.495^{c}$ & $0.569 \pm 0.005^{b}$ \\
\hline
\end{tabular}

Note: Values in each rows with different letters are significantly different at $P<0.05$ according to $S N K$ test. Values in rows with Same letters are not significantly different. 
Table(3): shows some chemical properties of Kasnazan impoundment water at different stations during studied area. Values expressed as a (mean \pm Standard Error).

\begin{tabular}{|c|c|c|c|c|c|c|}
\hline Stations & $\begin{array}{c}\mathbb{E C} \\
\mathrm{dS} \cdot \mathrm{m}^{-1}\end{array}$ & $\begin{array}{l}\text { Total hardness } \\
\left.\left(\mathrm{mg}^{-1}\right)^{-1}\right)\end{array}$ & $\begin{array}{c}\mathrm{Na}^{+} \\
\left(\mathrm{Meq}^{-1} \mathrm{I}^{-1}\right)\end{array}$ & $\begin{array}{l}\mathrm{Na}^{+} / \mathrm{Ca}^{+2} \\
\left(\mathrm{Meq} \mathrm{I}^{-1}\right)\end{array}$ & $\begin{array}{c}\mathrm{Mg}^{+2} / \mathrm{Ca}^{+2} \\
\left(\mathrm{Meq} \mathrm{I}^{-1}\right)\end{array}$ & $\begin{array}{c}\mathrm{Cl}^{-} \\
\left(\mathrm{Meq} \cdot \mathrm{I}^{-1}\right)\end{array}$ \\
\hline 1(Kahreez) & $0.606 \pm 0.051^{2}$ & $248 \pm 6.57^{\mathrm{a}}$ & $0.296 \pm 0.026^{2}$ & $2.09 \pm 0.114^{\mathrm{a}}$ & $1.39 \pm 0.330^{\mathrm{a}}$ & $0.408 \pm 0.052^{2}$ \\
\hline 2 & $0.450 \pm 0.603^{a}$ & $187 \pm 17.62^{\mathrm{a}}$ & $0.351 \pm 0.027^{\mathrm{a}}$ & $4.49 \pm 0.750^{\mathrm{a}}$ & $1.98 \pm 0.220^{\mathrm{a}}$ & $0.479 \pm 0.041^{2}$ \\
\hline 3 & $0.458 \pm 0.633^{2}$ & $187 \pm 17.62^{\mathrm{a}}$ & $0.337 \pm 0.032^{2}$ & $4.52 \pm 0.984^{\mathrm{a}}$ & $2.10 \pm 0.344^{2}$ & $0.409 \pm 0.038^{a}$ \\
\hline 4 & $0.444 \pm 0.605^{a}$ & $185 \pm 17.87^{\mathrm{a}}$ & $0.356 \pm 0.027^{\mathrm{a}}$ & $4.86 \pm 1.000^{\mathrm{a}}$ & $2.09 \pm 0.297^{a}$ & $0.399 \pm 0.041^{\mathrm{a}}$ \\
\hline 5 & $0.452 \pm 0.622^{a}$ & $184 \pm 18.19^{2}$ & $0.313 \pm 0.051^{2}$ & $4.30 \pm 1.210^{a}$ & $2.10 \pm 0.443^{2}$ & $0.369 \pm 0.030^{\mathrm{a}}$ \\
\hline
\end{tabular}

Note: Values in each rows with different letters are significantly different at $\mathrm{P}<0.05$ according to SNK test. Values in rows with same letters are not Significantly different.

Table(4): shows some chemical properties of Kasnazan impoundment water at different stations during studied area. Values expressed as a (mean \pm Standard Error).

\begin{tabular}{|c|c|c|c|c|c|c|}
\hline Stations & $\begin{array}{c}\mathbb{K}^{+} \\
\left(\mathrm{Meq}^{-1} \mathrm{I}^{-1}\right)\end{array}$ & $\begin{array}{c}\mathrm{HCO}^{-} \\
\left(\mathrm{Meq} \cdot \mathrm{I}^{-1}\right)\end{array}$ & $\begin{array}{c}\mathrm{Mg}^{+2} \\
\left(\mathrm{Meq}^{-1} \mathrm{I}^{-1}\right)\end{array}$ & SSP & SAR & SSPP \\
\hline 1 (Kahreez) & $0.054 \pm 0.0006^{2}$ & $0.046 \pm 0.001^{2}$ & $0.176 \pm 0.021^{a}$ & $43.91 \pm 3.42^{\mathrm{a}}$ & $0.514 \pm 0.034^{\mathrm{a}}$ & $0.728 \pm 0.086^{2}$ \\
\hline 2 & $0.067 \pm 0.010^{2}$ & $0.033 \pm 0.003^{b}$ & $0.164 \pm 0.015^{\mathrm{a}}$ & $52.08 \pm 3.51^{\mathrm{a}}$ & $0.612 \pm 0.037^{a}$ & $0.880 \pm 0.099^{a}$ \\
\hline 3 & $0.065 \pm 0.006^{a}$ & $0.033 \pm 0.033^{b}$ & $0.165 \pm 0.017^{a}$ & $50.95 \pm 3.80^{2}$ & $0.598 \pm 0.039^{\mathrm{a}}$ & $0.848 \pm 0.115^{2}$ \\
\hline 4 & $0.067 \pm 0.009^{2}$ & $0.031 \pm 0.032^{b}$ & $0.164 \pm 0.015^{a}$ & $52.48 \pm 3.93^{2}$ & $0.617 \pm 0.037^{\mathrm{a}}$ & $0.870 \pm 0.115^{a}$ \\
\hline 5 & $0.084 \pm 0.034^{a}$ & $0.032 \pm 0.030^{6}$ & $0.157 \pm 0.018^{a}$ & $46.90 \pm 5.23^{\mathrm{a}}$ & $0.568 \pm 0.063^{\mathrm{a}}$ & $0.833 \pm 0.162^{a}$ \\
\hline
\end{tabular}

Nore: Values in each rows with different letters are significantly different at $P<0.05$ according to SNK test. Values in rows with same letters are not Significantly different. 

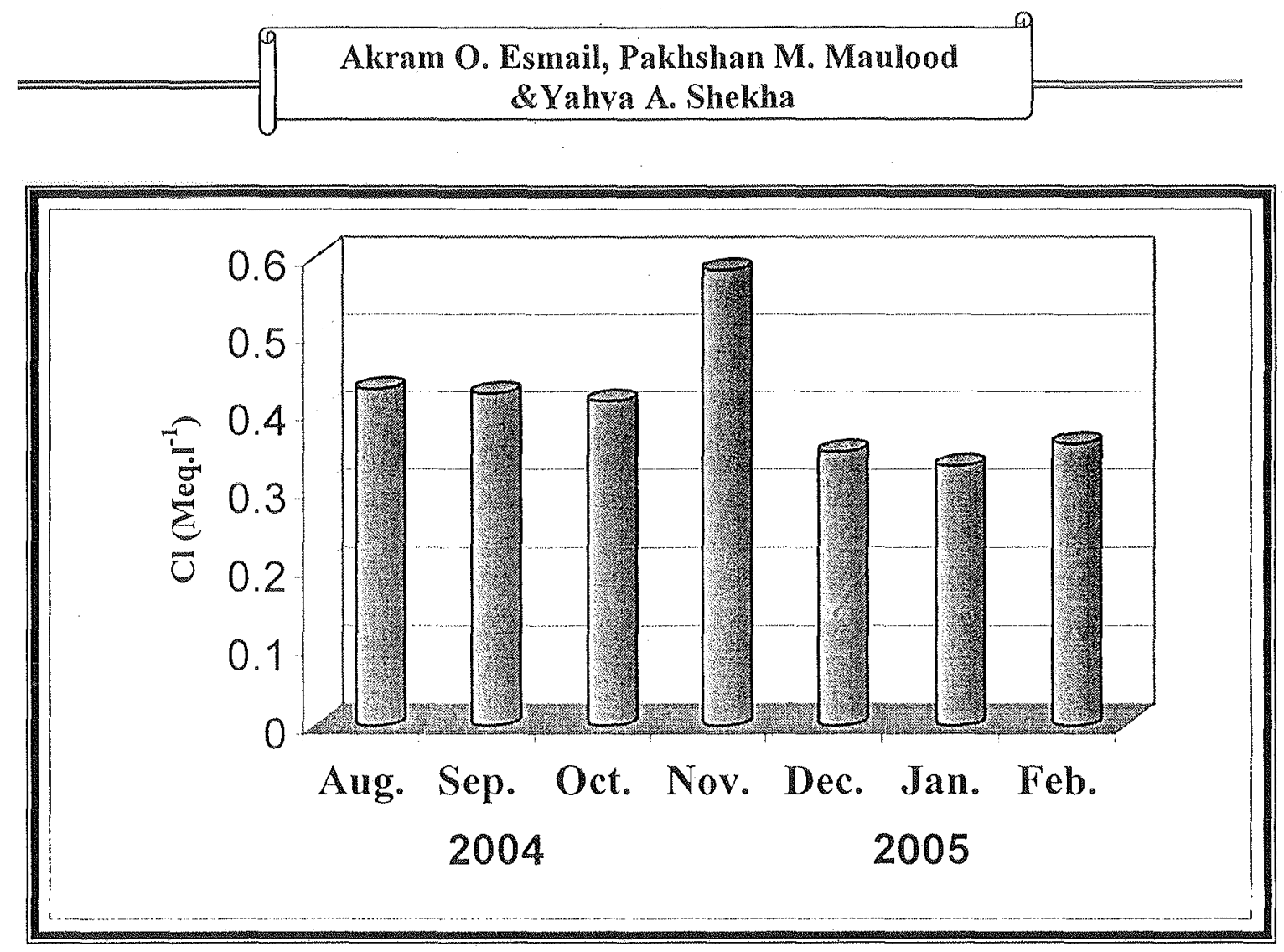

Fig(1): shows chloride concentration (Meq. $\mathrm{I}^{-1}$ ) in Kasnazan impoundment water during studied period.

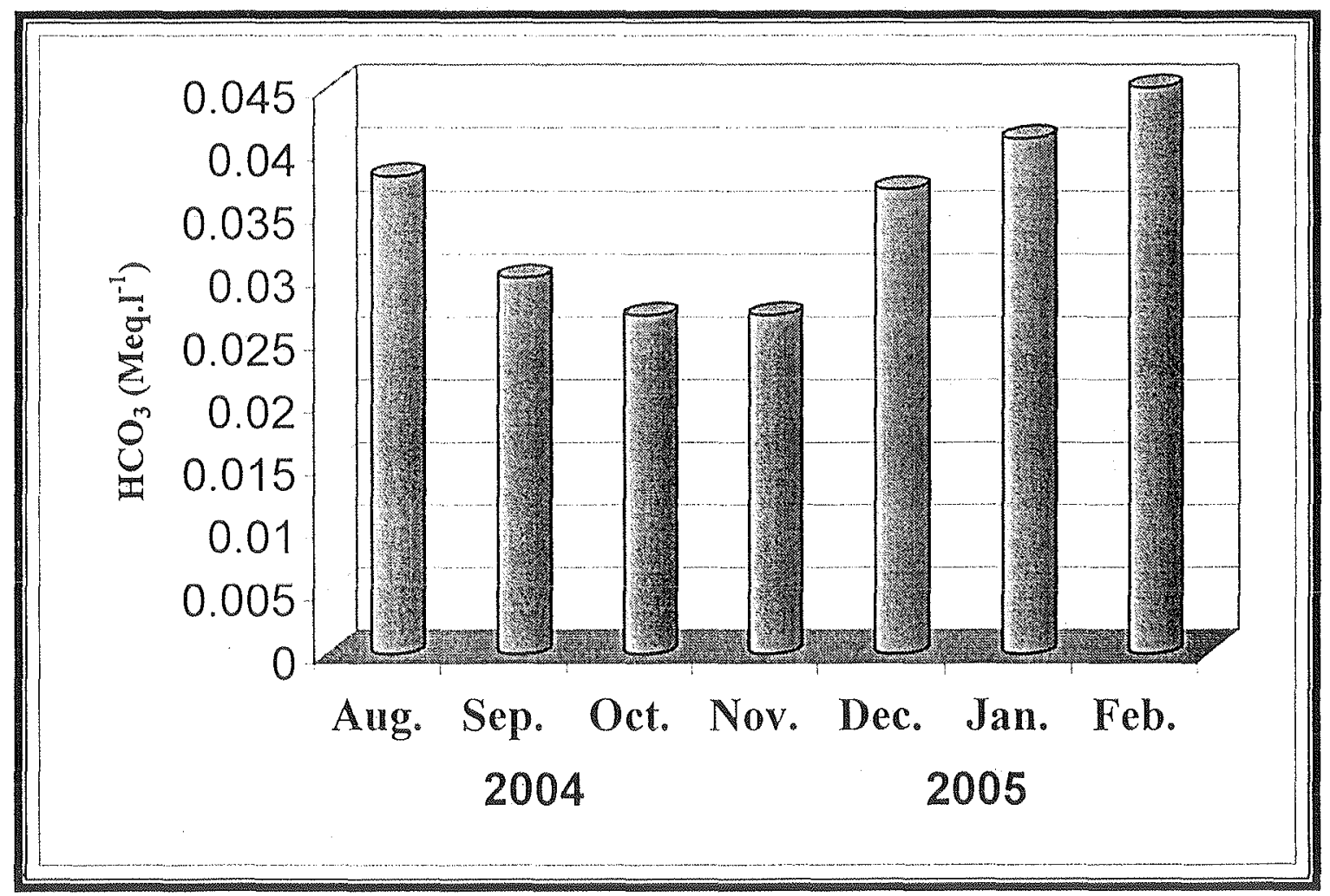

Fig(2): shows bicarbonate concentration (Meq..$^{-1}$ ) in Kasnazan impoundment water during studied period. 


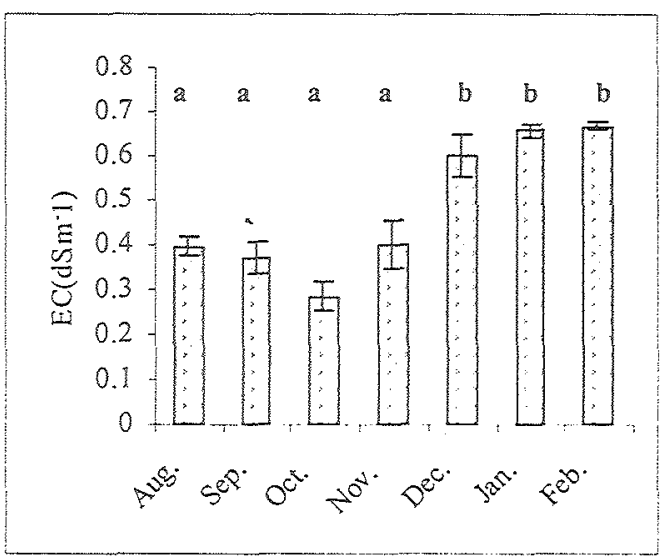

Fig(3): shows EC values(mean \pm S.E.) of Kasnazan impoundment water during studied period.

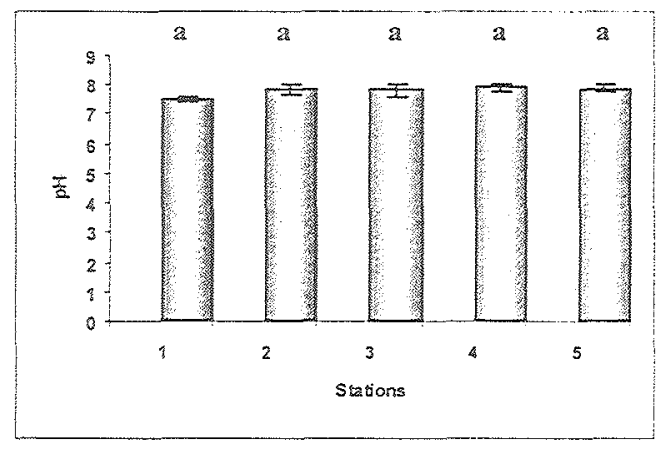

Fig(6): shows pH values(mean \pm S.E.) of different stations in Kasnazan imnoundment water.

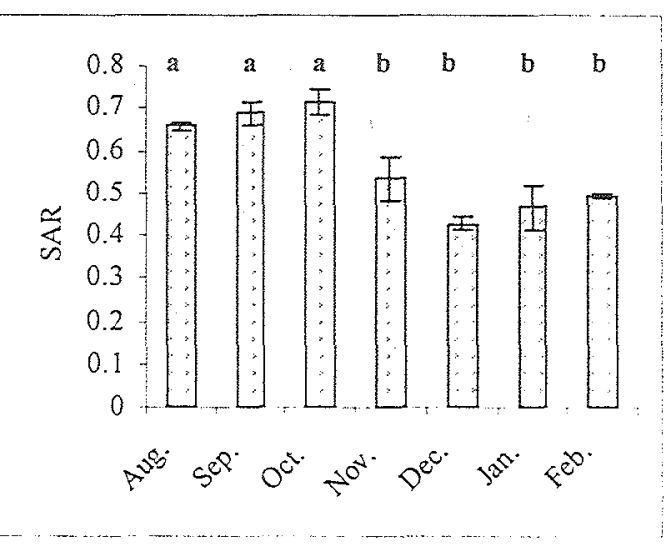

Fig(4): shows SAR values(mean \pm S.E.) of

Kasnazan impoundment water during studied period.

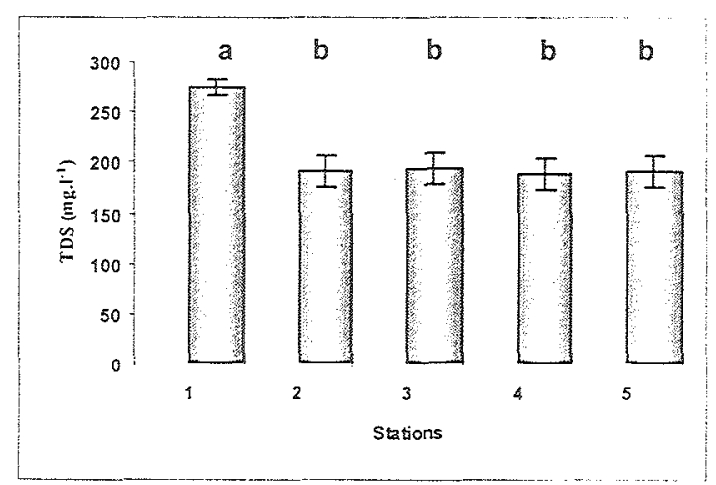

Fig(7): shows TDS values (mg..$^{-1}$ ) (mean \pm S.E.) of different stations in Kasnazan imnoundment water.

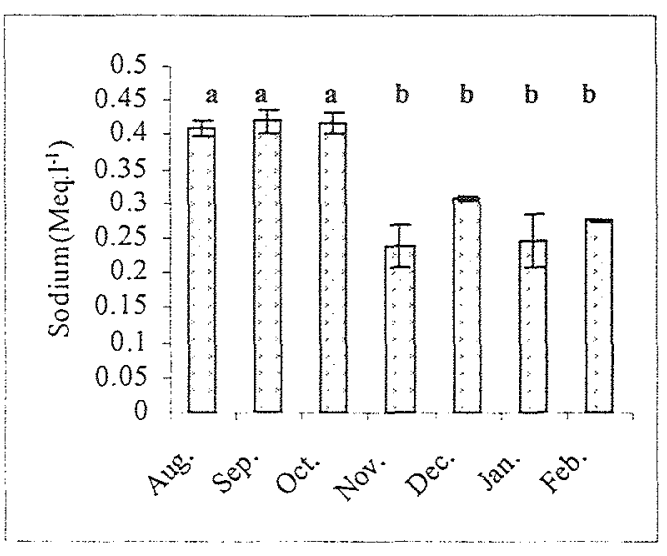

Fig(5): shows sodium (Meq..$\left.^{-1}\right)($ mean \pm S.E.) of Kasnazan impoundment water during studied period.

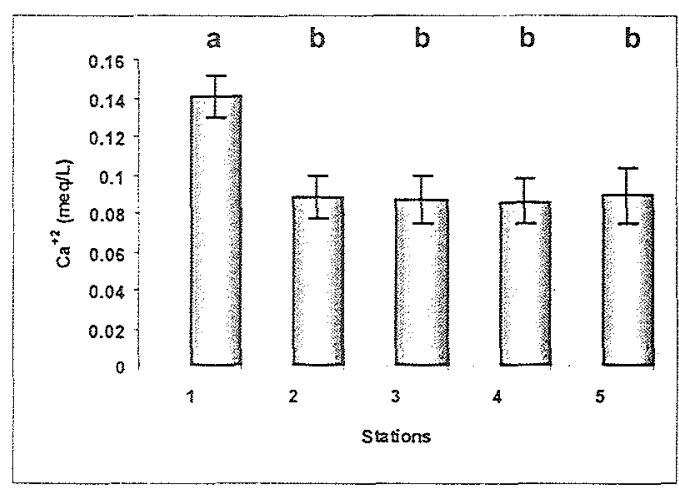

Fig(8): shows Calcium (Meq..$^{-1}$ ) (mean \pm S.E.) of different stations in Kasnazan imooundment water. 